\title{
ANISOTROPY OF NICKEL-BASE SUPERALLOY SINGLE CRYSTALS
}

\author{
by Rebecca A. MacKay,* \\ Robert L. Dreshfield,** \\ and Ralph D. Maier*
}

The influence of orientation on the tensize and stress rupture behavior of 52 Mar-M247 single crystals was studied. Tensile tests were performed at temperatures between $23^{\circ}$ and $1093^{\circ} \mathrm{C}$; stress rupture behavior was examined between $760^{\circ}$ and $1038^{\circ} \mathrm{C}$.

The mechanical behavior of the single crystals was rationatized on the basis of the Schmid factor contours for the operative slip systems and the lattice rotations which the crystals underwent during deformation. The tensile properties correlated well with the appropriate Schmid factor contours. The stress mpture lives at lower testing temperatures were greatly influenced by the lattice rotations required to produce cross slip.

A unified analysis was attained for the stress mpture Zife data generated for the Mar-M247 single crystals at $760^{\circ}$ and $774^{\circ} \mathrm{C}$ under a stress of $724 \mathrm{MPa}$ and the data reported for Mar-M200 single crystals tested at $760^{\circ} \mathrm{C}$ under a stress of $689 \mathrm{MPa}$. Based on this analysis, the stereographic triangle was divided into severat regions which were rank ordered according to stress rupture life for this temperature regime. This plot indicates the highest lives near the [111], high lives near the [001], and low lives near the [011]. Crystals within about $25^{\circ}$ of the [001] exhibited significantly ronger stress rupture lives when oriented closer to the [001] - [011] boundary than to the [001] - [111] boundary.

\footnotetext{
*Graduate Assistant and Assistant Professor, respectively, Department of Metallurgy and Materials Science, Case Western Reserve University, Cleveland, $\mathrm{OH} 44106$. **Metallurgist, NASA-Lewis Research Center, Cleveland, $\mathrm{OH}$ 44135.
} 


\section{INTRODUCTION}

Single crystal superalloys have been identified as an attractive approach for increasing allowable gas turbine blade temperatures. Among the requirements for successful application of single crystal airfoils is a fundamental understanding of the anisotropy of single crystals. The orientation and temperature dependence of Mar-M200 (Table 1) single crystals has been studied (1).* At $760^{\circ}$ and $871^{\circ} \mathrm{C}$, the longest stress rupture lives were found to occur for crystals oriented near the [001] and [ $\overline{1} 11]$; the shortest lives were exhibited by specimens oriented near the [011]. At $982^{\circ} \mathrm{C}$, the crystallographic orientations exerted much less influence on the stress rupture life. Mechanistic studies (2-4) revealed that during primary creep at $760^{\circ} \mathrm{C}(\mathrm{a} / 2)\langle 112\rangle$ dislocations were generated and then dissociated into $(a / 6)\langle 112\rangle$ and $(a / 3)\langle 112\rangle$ partials. These $(a / 3)\langle 112\rangle$ partial dislocations then controlled primary creep by shearing the $\gamma^{\dagger}$ precipitates by a diffusion-assisted process. Second-stage creep begins only after sutticient strain hardening occurs because of the intersection of $\{111\}\langle 112\rangle$ slip systems. Second-stage creep deformation is controlled by the shearing of the $\gamma^{\prime}$ by $(a / 2)\langle 110\rangle$ dislocation pairs. In contrast at $8570 \mathrm{C}$, pairs of $(a / 2)\langle 110\rangle$ dislocations shear the $\gamma^{\prime}$ in both primary and second-stage creep.

The purpose of the present work was to attain an improved understanding of the orientation dependence of the mechanical properties of Mar-M247 single crystals. This study evaluates the tensile and stress rupture properties generated for Mar-M247 single crystals and provides a unified analysis of this stress rupture data and that reported for Mar-M200.

\section{MATERIAL AND EXPERIMENTAL PROCEDURE}

Fifty-two single crystals of Mar-M247 (Table 1) were solution treated at $1232^{\circ} \mathrm{C}$ for 2 hours, argon quenched, aged at $816^{\circ} \mathrm{C}$ for 24 hours to promote precipitation, and air cooled. Tensile and stress rupture specimens, $0.63 \mathrm{~cm}$ diameter by $3.5 \mathrm{~cm}$ gage length, were prepared.

The initial orientations of the specimens, as we11 as the final orientations of selected crystals after mechanical testing, were determined by the Laue back-reflection X-ray method. Tensile tests were performed at $23^{\circ}, 649^{\circ}, 760^{\circ}, 871^{\circ}, 982^{\circ}$,

$\overline{*() \text { references }}$ are listed at the end of the text. 
and $1093^{\circ} \mathrm{C}$ according to ASTM E21. Stress rupture tests between $760^{\circ}$ and $1038^{\circ} \mathrm{C}$ were performed according to ASTM E-139-70.

\section{RESULTS AND DISCUSSION}

The orientations and tensile properties of eighteen single crystals tested are summarized in Table 2. The tensile behavior was rationalized on the basis of Schmid's Law which states that:

$$
\tau=\frac{P}{A} \cos \phi \cos \lambda
$$

where $\tau$ is the critical resolved shear stress (CRSS), P/A is the yield strength, $\phi$ is the angle between the normal to the slip plane and the tensile axis, $\lambda$ is the angle between the slip direction and the tensile axis, and $\cos \phi \cos \lambda$ is the Schmid factor.

The operative slip system for tensile testing up to $760^{\circ} \mathrm{C}$ is the (111) [101] slip system (2); the Schmid factor contours for this slip system are presented in Fig. 1. With the aid of this plot and the data in Table 2, the CRSS was determined to be essentially constant and equal to $400 \mathrm{MPa}$ for Mar-M247 single crystals tested from $23^{\circ}$ to $760^{\circ} \mathrm{C}$. Because of this fact, the tensile data for $23^{\circ}, 6490$, and $760^{\circ} \mathrm{C}$ could be grouped together and examined to determine the influence of orfentation on the tensile properties. The $0.02 \%$ yield strengths and percent elongations for Mar-M247 single crystals tested at these temperatures are presented as a function of initial orientation in Figs. 2(a) and (b), respectively. Comparison of these figures with the Schmid factor contours shown in Fig. 1 demonstrates that single crystals with high Schmid factors were favorably oriented for slip and therefore exhibit lower strengths and higher duclilities; those with low Schmid factors exhibited higher strengths and lower ductilities. At testing temperatures higher than $760^{\circ} \mathrm{C}$, additional slip systems became operative and higher ductilities and lower strengths resulted.

Thirty-four Mar-M247 single crystals were stress rupture tested between $760^{\circ}$ and $1038^{\circ} \mathrm{C}$; the results are summarized in Table 3. Comparison of the stress rupture data in Table 3 with the data reported in Ref. 1 shows that Mar-M200 and Mar-M247 single crystals have similar stress rupture strengths. The stress rupture lives and crystallographic orientations 
for selected Mar-M247 specimens tested at $774^{\circ}$ and $982^{\circ} \mathrm{C}$ are presented in Figs. 3(a) and (b), respectively. These figures and Table 3 demonstrate that the effect of initial orientation is much more pronounced at lower temperatures. This decrease in the anisotropy of the stress rupture behavior with increasing temperature is attributed to the increase in the number of operative slip systems which occurs with increasing temperature $(1,5)$. Consequently, this work was directed primarily at studying the stress rupture behavior at about $760^{\circ} \mathrm{C}$, where the anisotropy is prominent. The data obtained for Mar-M247 single crystals stress rupture tested at $760^{\circ}$ and $774^{\circ} \mathrm{C}$ under a stress of $724 \mathrm{MPa}$ and the data reported (1) for Mar-M200 single crystals, tested at $760^{\circ} \mathrm{C}$ under a stress of $689 \mathrm{MPa}$, were considered in this analysis. The Mar-M200 stress rupture data is presented in Fig. 4. In contrast to the analysis of the tensile data, comparison of the stress rupture data with the Schmid factor contours did not reveal a simple relationship. The primary factor which influenced the stress rupture life was determined to be the amount of lattice rotation required to produce cross slip.

The mechanisms involved during stress rupture testing are somewhat more complex than those for tensile testing. The $\{111\}\langle 112\rangle$ slip system rather than the (111) [T01] is operative during first-stage creep at $760^{\circ}$ and $774^{\circ} \mathrm{C}$ (4). The Schmid factor contours for the most highly stressed $\{111\}\langle 112\rangle$ slip systems are illustrated in Fig. 5. During plastic deformation, the single crystals rotate toward their slip direction. The rotations for the $\{111\}\langle 112\rangle$ and (111) [101] slip systems are shown in Figs. 6(a) and (b), respectively. The rotations determined by $\mathrm{X}$-ray analysis for specimens stress rupture tested at $774^{\circ} \mathrm{C}$ are illustrated in Fig. 7. Clearly, the $\{111\}\langle 112\rangle$ slip system is operative. The transition from first-stage to second-stage creep occurs only after sufficient intersecting slip strain hardens the material (2). Intersecting slip occurs for the $\{111\}\langle 112\rangle$ slip system along the $[001]-Y$ and $X-[\overline{1} 11]$ boundaries. Thus, second-stage creep cannot begin until the crystal has rotated to, or nearly to, one of these boundaries. During second-stage creep, the (111) [101] slip system becomes operative (4). The smaller the rotation required to initiate cross slip, the sooner second-stage creep will begin, and the longer the stress rupture life will be because second-stage creep proceeds much more slowly than primary creep. Thus, specimens oriented along directions of high symmetry exhibited the longest stress rupture lives because they were initially oriented for cross slip. Crystals which required large rotations to become oriented for cross slip had the shortest stress rupture 
lives. Crystals oriented such that small elongations caused them to rotate into intersecting slip orientations exhibited intermediate lives.

For example, crystal 157 in Fig. 7 had an approximate [11] orientation and exhibited the longest stress rupture life of 1242 hours. This behavior is attributed to the cross slip and to the minimum in schmid factor for both first and second-stage creep that occur for this orientation. A stress rupture life of 179 hours was exhibited by specimen 1 which was oriented near the [001], as shown in Fig. 7. Although this crystal was oriented for multiple slip, it was not located in a low Schmid factor region, and a life significantly lower than that of the [I11] crystal resulted. Specimen 158 was oriented near the [011] and had a life of 1 hour. As shown in Fig. 7, this crystal rotated through regions of high Schmid factor toward its slip direction during first-stage creep and failed before reaching the $\mathrm{X}-[\overline{111}]$ boundary. This crystal exhibited an extremely short life because it did not benefit from the strengthening effects of cross slip.

The Larson-Miller parameter plot shown in Fig. 8 presents stress rupture data for single crystals of Mar-M247 and Mar-M200. The values for Mar-M247 were generated in this study; those for Mar-M200 were computed from the data reported in the literature (1). A dashed line was constructed using the minimum values for the alloys at each stress level, and a second dashed line was constructed using the maximum values for the alloys at each stress level. The solid line displayed represents conventionally cast Mar-M200 (6) and is presented for comparison. The substantial increase in Larson-Miller parameter of an approximate [111] orientation over that of an approximate [001] orientation for $\operatorname{Mar}-M 247$ is clearly evident. This increase in Larson-Miller parameter represents an increase of almost an order of magnitude in the stress rupture life of the [I11] crystal over that for the [001] crystal and demonstrates that the [i11] orientation provides the best creep-resistance and the longest stress rupture lives. It is also apparent from Fig. 8 that unfavorably oriented single crystals, such as those with an [011] orientation, exhibit stress rupture lives which are shorter than the stress rupture lives of conventionally cast Mar-M200. At lower stress levels and higher testing temperatures, the orientation dependency is not as pronounced because multiple slip occurs at more elevated temperatures for Mar-M200 $(1,5)$.

Based on a consideration of the lattice rotations and the Schmid factors for the stress rupture life data of Mar-M247 single crystals tested at $760^{\circ}$ and $774^{\circ} \mathrm{C}$ and the 
data reported for Mar-M200 single crystals tested at $760^{\circ} \mathrm{C}$, the standard stereographic trlangle was divided into several regions which were rank ordered according to stress rupture life for this temperature regime. This plot shown in Fig. 9 indicates the highest lives near the [111], high lives near the [001], and low lives near the [011]. Crystals within about $25^{\circ}$ of the [001] exhibited longer stress rupture lives when oriented_closer to the [001] - [011] boundary than to the [001] - [111] boundary because crystals closer to the [001] - [011] boundary do not have to rotate as far before reaching intersecting slip regions during first-stage creep. This latter finding has commercial significance; although the [111] orientation may be the most creep-resistant, crystals oriented near the [001] are utilized for most turbine blade applications because their low elastic modulus (1) provides improved thermal fatigue resistance. Thus, this plot should assist in establishing standards for commercially acceptable orientations.

\section{CONCLUSIONS}

1. During tensile testing between $23^{\circ}$ and $760^{\circ} \mathrm{C}$, single crystals with high Schmid factors were favorably oriented for slip and exhibited lower strengths and higher ductilities; those with low Schmid factors exhibited higher strengths and lower ductilities.

2. During stress rupture testing at about $760^{\circ} \mathrm{C}$, crystals which required large rotations to become oriented for cross slip had the shortest lives; those which required little or no rotations had the longest lives.

3. Although crystals near the [001] and [ $\overline{1} 11]$ were both

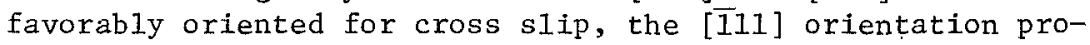
vided much longer stress rupture lives because of lower Schmid factors.

4. Crystals oriented within about $25^{\circ}$ of the [001] exhibit longer stress rupture lives when oriented closer to the [001] - [011] boundary than to the [001] - [111] boundary for stress rupture testing at $760^{\circ}$ and $774^{\circ} \mathrm{C}$.

\section{ACKNOWLEDGMENTS}

This work was funded in part by NASA grant NSG-3246. The authors also wish to acknowlcdge many useful discussions with R. G. Garlick and M. I. Alley of the Lewis Research Center. 
RFFERFNCES

(1) B. H. Kear and B. J. Piearcey: Trans. TMS-AIME, 1967, vo1. 239, pp. 1209-15.

(2) G. R. Leverant and B. H. Kear: Meta11. Trans., 1970, vo1. 1, pp. 491-98.

(3) B. H. Kear, G. R. Leverant, and J. M. Oblak: Trans. ASM, 1969, vol. 62, pp. 639-50.

(4) G. R. Leverant, B. H. Kear, and J. M. Oblak: Meta11. Trans., 1973, vo1. 4, pp. 355-62.

(5) D. N. Duhl, et. al.: Presented at 1979 TMS-AIME Fall Meeting.

(6) N. S. Stoloff: in Alloy and Microstructural Design, J. K. Tien and G. S. Ansell, eds., p. 104, Academic Press, New York, 1976.

Table 1. - Compositions of Selected Nicke1-Base Superalloys (wt.z)

\begin{tabular}{|c|c|c|c|c|c|c|c|c|c|c|c|c|}
\hline 10 & $\underline{\mathbf{C}}$ & $\underline{\text { Cr }}$ & So & T1 & A1 & $\underline{\underline{W}}$ & $\underline{\mathrm{Zr}}$ & B & $\underline{\mathbf{F e}}$ & 쓰 & TE & ㅂf \\
\hline & .15 & & & & & $\begin{array}{r}9.9 \\
\end{array}$ & 0.07 & & $1.5 \mathrm{max}$ & 0.75 & 3.1 & 1.5 \\
\hline
\end{tabular}

Table 2. - Tens1le Testing of Mar-M247 S1ng1e Crystale

\begin{tabular}{|c|c|c|c|c|c|c|c|c|c|}
\hline $\begin{array}{l}\text { Spec. } \\
\text { no. }\end{array}$ & $\begin{array}{c}\text { Temp. } \\
\text { oC } \\
\end{array}$ & $\begin{array}{l}\text { UTS, } \\
\text { MPa }\end{array}$ & $\begin{array}{r}0.02 \mathrm{X} \text { Y.S., } \\
\mathrm{MPa}\end{array}$ & $\begin{array}{r}0.22 \mathrm{Y} . \mathrm{S} ., \\
\mathrm{MPa}\end{array}$ & $\begin{array}{c}\text { Elone., } \\
\mathrm{x}\end{array}$ & $\begin{array}{r}\text { R.A., } \\
\quad \\
\end{array}$ & $\begin{array}{r}\mathbf{R}, \\
\text { MP a } \\
\end{array}$ & $\begin{array}{l}\text { Orient } \\
\text { degrees } \\
1001]\end{array}$ & $\begin{array}{l}\text { Ation } \\
\text { from: } \\
\text { Lo11] }\end{array}$ \\
\hline $\begin{array}{l}40 \\
49 \\
54\end{array}$ & $\begin{array}{l}23 \\
23 \\
23\end{array}$ & $\begin{array}{l}965 \\
951 \\
935\end{array}$ & $\begin{array}{l}860 \\
836 \\
859\end{array}$ & $\begin{array}{l}934 \\
904 \\
912\end{array}$ & $\begin{array}{r}7 \\
11 \\
9\end{array}$ & $\begin{array}{l}11 \\
14 \\
14\end{array}$ & $\begin{array}{l}136 \\
140 \\
142\end{array}$ & $\begin{array}{c}10 \\
7.5 \\
12.5\end{array}$ & $\begin{array}{l}35 \\
38 \\
33\end{array}$ \\
\hline $\begin{array}{l}55 \\
58 \\
60\end{array}$ & $\begin{array}{l}649 \\
649 \\
649\end{array}$ & $\begin{array}{r}848 \\
915 \\
1025\end{array}$ & $\begin{array}{l}788 \\
800 \\
923\end{array}$ & $\begin{array}{l}806 \\
849 \\
941\end{array}$ & $\begin{array}{r}13 \\
11 \\
6\end{array}$ & $\begin{array}{r}15 \\
14 \\
9\end{array}$ & $\begin{array}{l}130 \\
112 \\
112\end{array}$ & $\begin{array}{c}18 \\
14 \\
6.5\end{array}$ & $\begin{array}{l}27.5 \\
31 \\
39\end{array}$ \\
\hline $\begin{array}{l}64 \\
76 \\
79\end{array}$ & $\begin{array}{l}760 \\
760 \\
760\end{array}$ & $\begin{array}{r}1093 \\
969 \\
1054\end{array}$ & $\begin{array}{l}876 \\
829 \\
855\end{array}$ & $\begin{array}{l}902 \\
863 \\
867\end{array}$ & $\begin{array}{l}8 \\
9 \\
8\end{array}$ & $\begin{array}{r}8 \\
5 \\
10\end{array}$ & $\begin{array}{l}104 \\
185 \\
111\end{array}$ & $\begin{array}{l}6.5 \\
35 \\
12.5\end{array}$ & $\begin{array}{l}39.5 \\
26.5 \\
34.5\end{array}$ \\
\hline $\begin{array}{r}82 \\
119 \\
120\end{array}$ & $\begin{array}{l}871 \\
871 \\
871\end{array}$ & $\begin{array}{l}920 \\
885 \\
938\end{array}$ & $\begin{array}{l}698 \\
718 \\
643\end{array}$ & $\begin{array}{l}798 \\
812 \\
783\end{array}$ & $\begin{array}{l}9 \\
6 \\
8\end{array}$ & $\begin{array}{r}9 \\
10 \\
9\end{array}$ & $\begin{array}{r}125 \\
131 \\
92\end{array}$ & $\begin{array}{r}18 \\
25 \\
6\end{array}$ & $\begin{array}{l}28.5 \\
20.5 \\
39.5\end{array}$ \\
\hline $\begin{array}{l}121 \\
122 \\
124\end{array}$ & $\begin{array}{l}982 \\
982 \\
982\end{array}$ & $\begin{array}{l}586 \\
541 \\
603\end{array}$ & $\begin{array}{l}400 \\
407 \\
342\end{array}$ & $\begin{array}{l}440 \\
502 \\
432\end{array}$ & $\begin{array}{l}16 \\
20 \\
20\end{array}$ & $\begin{array}{l}23 \\
29 \\
21\end{array}$ & $\begin{array}{r}83 \\
163 \\
178\end{array}$ & $\begin{array}{l}23 \\
45 \\
42\end{array}$ & $\begin{array}{l}25.5 \\
16.5 \\
28\end{array}$ \\
\hline $\begin{array}{l}125 \\
129 \\
130\end{array}$ & $\begin{array}{l}1093 \\
1093 \\
1093\end{array}$ & $\begin{array}{l}310 \\
274 \\
281\end{array}$ & $\begin{array}{l}216 \\
158 \\
---\end{array}$ & $\begin{array}{l}259 \\
208 \\
-\end{array}$ & $\begin{array}{l}16 \\
17 \\
28\end{array}$ & $\begin{array}{l}37 \\
51 \\
37\end{array}$ & $\begin{array}{r}67 \\
85 \\
--\end{array}$ & $\begin{array}{l}21.5 \\
13.5 \\
44\end{array}$ & $\begin{array}{l}30 \\
31 \\
21.5\end{array}$ \\
\hline
\end{tabular}


Table 3. - Stress Rupture Testing of Mar-M247 Single Crystals

\begin{tabular}{|c|c|c|c|c|c|c|c|}
\hline $\begin{array}{l}\text { Spec. } \\
\text { no. }\end{array}$ & $\begin{array}{c}\text { Temp. , } \\
{ }^{\circ} \mathrm{C} \\
\end{array}$ & $\begin{array}{c}\text { Stress, } \\
\mathrm{MPa} \\
\end{array}$ & $\begin{array}{l}\text { Life, } \\
\text { hr }\end{array}$ & $\begin{array}{c}\text { Elong., } \\
\% \\
\end{array}$ & $\begin{array}{c}\text { R.A., } \\
\%\end{array}$ & \multicolumn{2}{|c|}{$\begin{array}{c}\text { Orlentation } \\
\text { degrees from: } \\
\text { [001] [011] }\end{array}$} \\
\hline $\begin{array}{r}35 \\
161 \\
143\end{array}$ & $\begin{array}{l}760 \\
760 \\
760\end{array}$ & $\begin{array}{l}724 \\
724 \\
689\end{array}$ & $\begin{array}{c}131 \\
231 \\
1005+\end{array}$ & $\begin{array}{r}13 \\
15 \\
3\end{array}$ & $\begin{array}{r}8 \\
16 \\
--\end{array}$ & $\begin{array}{c}4.5 \\
5 \\
45.5\end{array}$ & $\begin{array}{l}41.5 \\
40 \\
31.5\end{array}$ \\
\hline $\begin{array}{r}1 \\
72 \\
74 \\
123 \\
128 \\
147 \\
157 \\
158\end{array}$ & $\begin{array}{c}774 \\
1\end{array}$ & 724 & $\begin{array}{r}179 \\
26 \\
21 \\
37 \\
20 \\
138 \\
1242 \\
1\end{array}$ & $\begin{array}{r}16 \\
9 \\
11 \\
12 \\
8 \\
8 \\
11 \\
24\end{array}$ & $\begin{array}{l}15 \\
12 \\
13 \\
15 \\
12 \\
15 \\
12 \\
28\end{array}$ & $\begin{array}{r}3 \\
7 \\
10 \\
8 \\
28 \\
45 \\
52.5 \\
39\end{array}$ & $\begin{array}{l}42 \\
38.5 \\
36 \\
37.5 \\
17 \\
28 \\
34.5 \\
7\end{array}$ \\
\hline $\begin{array}{l}23 \\
20 \\
24\end{array}$ & $\begin{array}{l}816 \\
843 \\
843\end{array}$ & $\begin{array}{l}448 \\
379 \\
345\end{array}$ & $\begin{array}{l}1889 \\
2005 \\
2183\end{array}$ & $\begin{array}{r}30 \\
6 \\
32\end{array}$ & $\begin{array}{r}31 \\
7 \\
41\end{array}$ & $\begin{array}{l}5 \\
4 I .5 \\
9\end{array}$ & $\begin{array}{l}41 \\
27.5 \\
39\end{array}$ \\
\hline $\begin{array}{r}19 \\
28 \\
37 \\
71 \\
132 \\
152 \\
162 \\
135\end{array}$ & 871 & $\begin{array}{c}\downarrow \\
414 \\
414 \\
448\end{array}$ & $\begin{array}{r}561 \\
229 \\
377 \\
247 \\
414 \\
447 \\
481 \\
92\end{array}$ & $\begin{array}{r}15 \\
30 \\
30 \\
28 \\
28 \\
8 \\
12 \\
8\end{array}$ & $\begin{array}{l}33 \\
37 \\
43 \\
30 \\
42 \\
13 \\
14 \\
10\end{array}$ & $\begin{array}{r}35 \\
18 \\
6 \\
4 \\
5 \\
34 \\
50.5 \\
31\end{array}$ & $\begin{array}{l}16.5 \\
29.5 \\
39 \\
42.5 \\
40 \\
30 \\
25.5 \\
23\end{array}$ \\
\hline $\begin{array}{r}17 \\
6 \\
27 \\
53 \\
133 \\
156 \\
136 \\
163\end{array}$ & $\begin{array}{c}982 \\
\end{array}$ & $\begin{array}{c}172 \\
207\end{array}$ & $\begin{array}{r}256 \\
70 \\
99 \\
91 \\
190 \\
83 \\
86 \\
56\end{array}$ & $\begin{array}{l}43 \\
36 \\
34 \\
33 \\
33 \\
22 \\
26 \\
36\end{array}$ & $\begin{array}{l}55 \\
60 \\
56 \\
59 \\
40 \\
36 \\
33 \\
57\end{array}$ & $\begin{array}{c}24.5 \\
10 \\
7.5 \\
4 \\
32 \\
40 \\
30 \\
6\end{array}$ & $\begin{array}{l}21 \\
35.5 \\
39 \\
41.5 \\
28 \\
6.5 \\
24.5 \\
42.5\end{array}$ \\
\hline $\begin{array}{r}2 \\
25 \\
16\end{array}$ & $\begin{array}{l}1010 \\
1010 \\
1038\end{array}$ & $\begin{array}{l}138 \\
172 \\
138\end{array}$ & $\begin{array}{r}192 \\
68 \\
82\end{array}$ & $\begin{array}{l}21 \\
31 \\
36\end{array}$ & $\begin{array}{l}34 \\
36 \\
62\end{array}$ & $\begin{array}{l}19 \\
38 \\
10\end{array}$ & $\begin{array}{l}29.5 \\
14 \\
37.5\end{array}$ \\
\hline
\end{tabular}

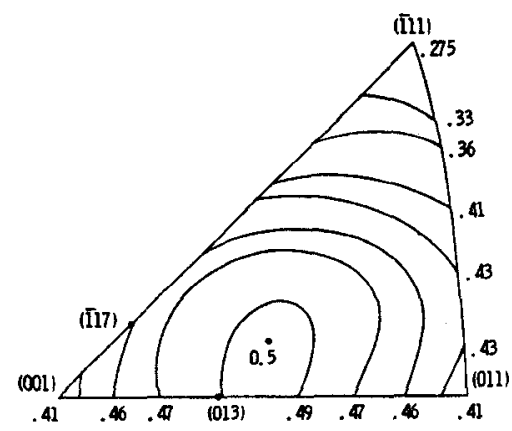

Figure 1. - Schmid factor contours for the (111) [īol] slip system (1). 


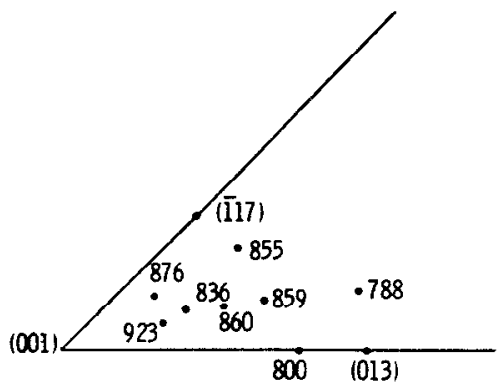

(a) 0.02 percent $Y . S ., M P a$.

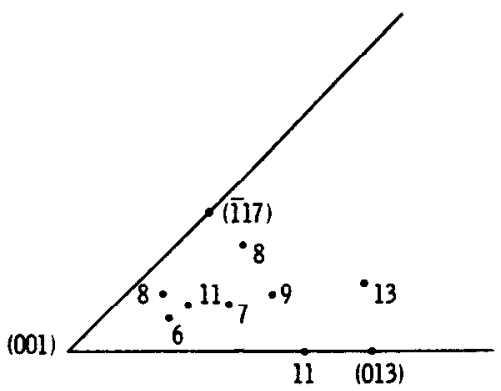

(b) ELONGATIONS, percent.

Figure 2 - Stereographic triangles showing yield strength and elongation of Mar-M247 single crystals tensile tested at $2^{\circ}, 649^{\circ}$, and $760^{\circ} \mathrm{C}$.

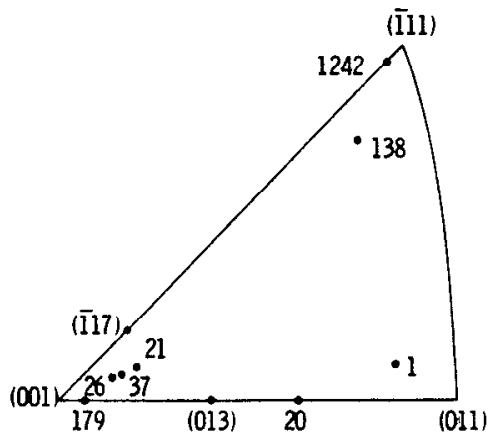

(a) $774^{\circ} \mathrm{C}, 724 \mathrm{MPa}$.

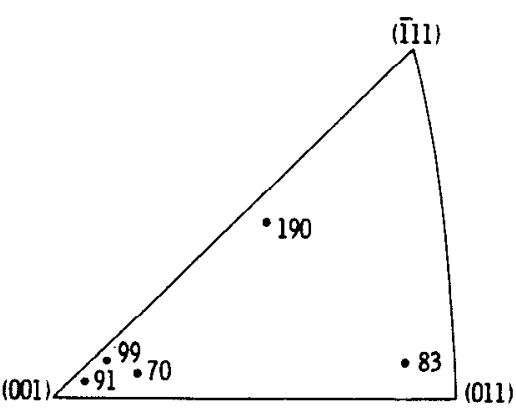

(b) $982^{\circ} \mathrm{C}, 207 \mathrm{MPa}$.

Figure 3. - Stress rupture lives as a function of orientation for Mar-M247 single crystals.

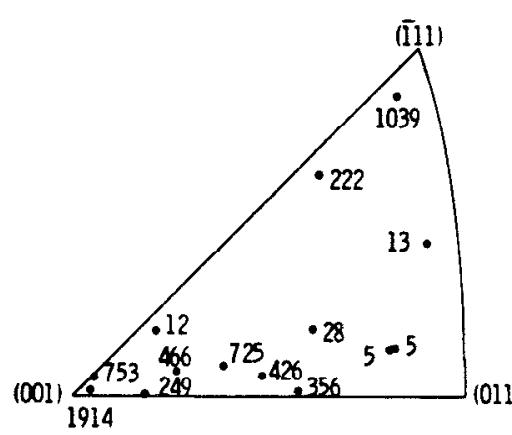

Figure 4. - Stress rupture lives as a function of orientation for Mar $-\mathrm{M} 200$ single crystals at $760^{\circ} \mathrm{C}$ and $689 \mathrm{MPa}(1)$.

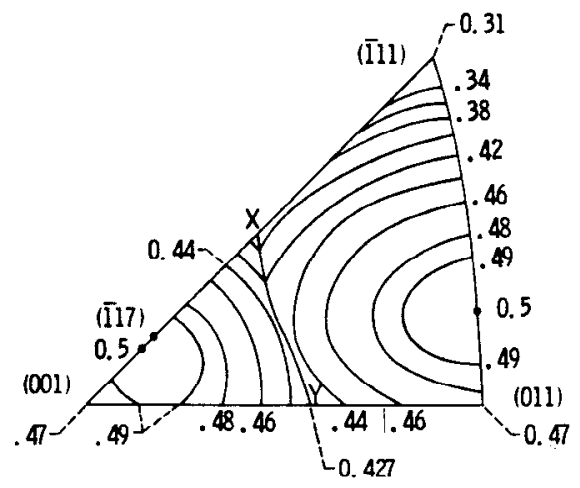

Figure 5. - Schmid factor contours for the most highly stressed \{111\}〈112〉 slip system (2). 

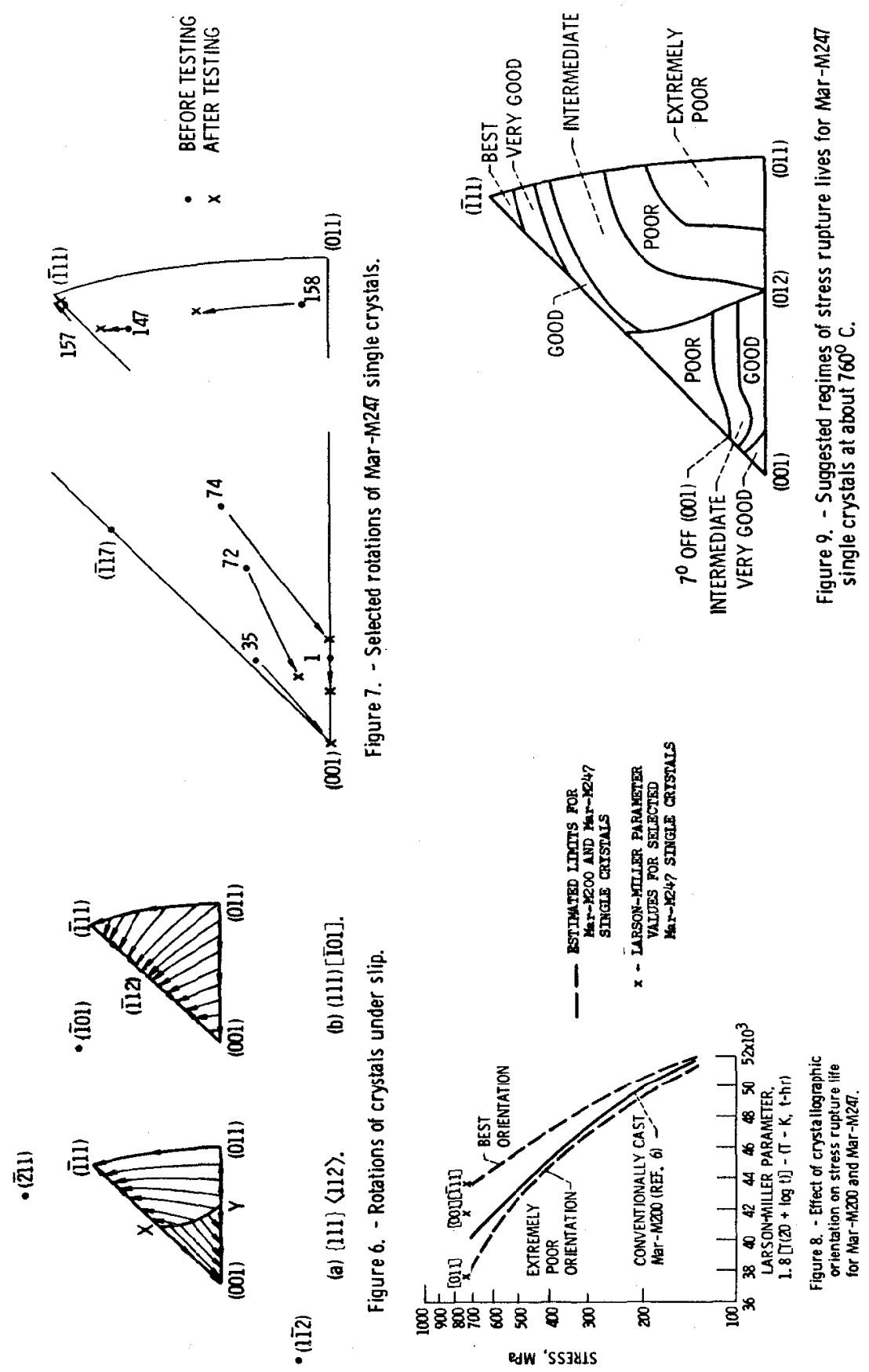